Running Head: ESTIMATING WARSHIP DEPOT MAINTENANCE DURATIONS

\author{
Estimating Warship Depot Maintenance Durations
}

Christopher M. Williams, Ph.D.

CMW Research, LLC

\begin{abstract}
U.S. Navy Surface Ship depot-level maintenance periods of performance were studied to develop a method for predicting maintenance durations. The need for the method has been highlighted by Navy leadership in recent media posts describing unacceptable maintenance delays and this research provides practitioners and decisionmakers with a reliable estimating tool. This study helps by putting forth a method that defines the rate of work accomplishment based on relevant variables. Using ordinary least squares models, this research revealed that the size of the contract obligation and the amount of shipyard work occurring simultaneously in the market are key variables in determining depot maintenance durations. With the knowledge found here, the next logical step is an optimization model for each U.S. Navy surface ship homeport.
\end{abstract}

Keywords: Surface Ship, Depot-Level Maintenance, Predictive Modeling 
Running Head: ESTIMATING WARSHIP DEPOT MAINTENANCE DURATIONS

\section{Estimating Warship Depot Maintenance Durations}

\section{Introduction}

This paper puts forth a method for estimating U.S. Navy surface ship depot maintenance contract periods of performance. Some ship maintenance can only be performed while in a shipyard and based on recent media (Eckstein, 2020) and U.S. Government Accountability Office (GAO) reporting $(2019,2020)$, warship maintenance delays are a salient issue across public and private ship repair yards in the United States. The Navy operates four public-owned shipyards, but they are primarily engaged in aircraft carrier and submarine maintenance (Martin et al., 2017) leaving the private market as the primary provider of shipyard maintenance for surface ships. This research focuses solely on analyzing the production rates of U.S. private shipyards that are contracted for repairs on U.S. Navy surface vessels.

Shipyards in the U.S. are generally engaged in shipbuilding or in ship repair and the yards that maintained the Navy's surface fleet between 2010 and 2020 are predominantly from the ship repair category. Also, with the exception of certain forward deployed vessels, ${ }^{1}$ the U.S. is the only place where certain heavy industrial maintenance actions can be performed. The Maintenance Policy for Navy Ships (Chief of Naval Operations, 2019) calls this type of work "Depot-Level Maintenance" (p. 65), and points out that these repairs are beyond the capability of the ships' crews and the Navy's intermediate maintenance facilities. The private sector helps to meet the Navy's demand for repairs, but there are only a few shipyards in each homeport where this type of maintenance can occur which can cause a disequilibrium in the private markets. This research explores U.S. shipyards' contracting histories with the federal government to develop a

\footnotetext{
${ }^{1}$ Forward deployed vessels refer to vessels that are homeported overseas and/or have Title 10 Exemptions for maintenance in foreign shipyards per 10 U.S. Code $\$ 8680$ - Overhaul, repair, etc. of vessels in foreign shipyards.
} 
better understanding of factors that influence repair duration which is necessary in order to develop a method for predicting future outcomes.

Shipyard maintenance delays can conceivably result from a few different phenomena. First, force majeure or punctuated impacts on a shipyard region and its resources can impact fixed and natural assets, supply chains and labor forces. For example, every hurricane season on the U.S. East Coast presents some risk to on-time accomplishment of shipyard maintenance. Second, once a ship enters a shipyard and opens its systems for inspections and repairs there is potential for unforeseen growth and new work. The discovery of growth and new work can trigger contract modifications that extend repair durations. Third, some ships' systems are highly unique and parts are not readily available through Navy logistics or on the open market. Waiting on specialized parts can extend overall maintenance durations. Lastly, there is no clear understanding of industry production rates from which to develop reliable estimates. This study focuses on the latter - developing a method that allows practitioners and Navy leadership to estimate reliable durations with up-front and verifiable accuracy.

This research is important for two reasons. First, the ability to accurately determine how long a warship will be offline for maintenance is important to the Navy for scheduling purposes. The Atlantic and Pacific Surface Fleet Commanders (COMNAVSURFPAC/LANT) make warships ready for sustained operations (i.e., deployments) through a process codified in the Surface Force Training and Readiness Manual (2018) and a solid understanding of maintenance durations will aid the Navy in readying warships for combat operations. Second, the inability to accurately set a contract period of performance for a specified level of effort can cause peaks and valleys in local employment levels making it difficult for the private sector to retain a skilled workforce (Kalafsky, 2008). 
The federal obligation data for this study suggests that the depot-level maintenance markets at each surface ship homeport are involved almost exclusively in repairing or building government vessels. If this is the case, there are likely relationships within the contract cost and period of performance data that can be used for predictive purposes. Using total federal obligations in each homeport and the time-cost relationship described in the civil engineering literature (Bromilow, 1974; Czarnigowska \& Sobotk, 2013), this research develops an estimation method to understand the forces that influence depot-level maintenance durations. In order to develop the required knowledge, three research questions are addressed:

1) What private shipyards make up the surface ship depot-level maintenance markets?

2) Does the total of federal agencies' contract obligations with the individual markets impact surface ships' depot maintenance durations?

3) Can the relationship between depot maintenance cost and duration be used to estimate future outcomes?

\section{Background}

This section describes the depot-level maintenance market, discusses the impacts of maintenance delays on the workforce and national defense and introduces the duration estimation methodology. First, the private industrial market is described where the Navy's surface ships are homeported and maintained. Second, industry impacts are discussed based on observations made using Navy (financial) obligations and workforce levels. Third, the impacts of maintenance delays on national defense are explained. Lastly, a theoretical underpinning is discussed that supports the variables defined in Section 3. 
Running Head: ESTIMATING WARSHIP DEPOT MAINTENANCE DURATIONS

\subsection{The U.S. shipbuilding and repair market.}

The post-Cold War era brought changes to the Navy's force structure and the reduction translated to a decreased demand for ship repair. By the early 2000s the industry that enjoyed 179,000 employees in 1981 had been reduced by half, until it began to increase again in 2008 (National Bureau of Economic Research, 2014). By the end of 2019 the U.S. industry employed 137,808 employees (U.S. Bureau of Labor Statistics, 2 Dec 2020) and the decline between 1981 and the early 2000s was likely facilitated by the Navy's force reduction that followed the end of the Cold War. Fortunately, the industry is getting back to pre-cold war levels which will help the nation build and maintain larger Navy and merchant fleets.

Further confounding the capacity issue is the size of the market at each homeport. There are only a few of shipyards in each homeport that are contracted for depot-level maintenance which could exacerbate the maintenance delay issues in times of peak demand. Shipyards require a large amount of capital to construct and maintain fixed assets and a waterfront location with navigable access for ships to enter and exit the facility. These requirements make it difficult for new players to enter the market and have the potential to constrain the industry. In order to develop an estimation method, the remainder of this study focuses solely on the shipyards that were contracted to perform depot-level maintenance on surface ships (called participating shipyards hereafter).

\subsubsection{Surface ship depot-level maintenance markets.}

There are five locations in the United States where surface ships are homeported and conduct depot-level maintenance: Everett, WA; Mayport, FL; Norfolk, VA; Pearl Harbor, HI; and San Diego, CA (Naval Vessel Register, December 2, 2020). Each of these homeports have more than one private shipyard forming a market where service providers compete for 
Running Head: ESTIMATING WARSHIP DEPOT MAINTENANCE DURATIONS

government and commercial work. For this research the market is defined as those shipyards that received federal awards for the purpose of completing planned depot-level maintenance on U.S. Navy surface vessels. The private shipyards making up each market are included in the Appendix.

The U.S. federal government funds shipyard maintenance in the homeport markets through a few different departments: Army, Navy, and Military Sealift Command (MSC) vessels and equipment are funded by the Department of Defense; U.S. Coast Guard cutters are funded by the Department of Homeland Security; and the Department of Transportation funds a small amount of shipyard work through the U.S. Maritime Administration (MARAD). In some cases, multiple federal agencies contract with the same shipyards that perform maintenance on U.S. Navy surface ships. Table 1 illustrates U.S. federal agency market shares. It is important to note that the San Diego market is engaged in shipbuilding which explains the size of the Navy obligations compared to other homeport markets.

Table 1. Participating Shipyard Federal Obligations FY 2010-2020

\begin{tabular}{lrrrrrr}
\hline \multicolumn{1}{c}{ Homeport } & $\left.\begin{array}{r}\text { Obligations } \\
(\text { USD x 10 }\end{array}\right)$ & \multicolumn{5}{c}{ Percent of U.S. Federal Obligations } \\
Everett, WA & 1.45 & 89.2 & 0.0 & 10.4 & 0.4 & 0.0 \\
Pearl Harbor, HI & 1.07 & 96.6 & 1.5 & 1.5 & 0.5 & 0.0 \\
Mayport Fl & 1.81 & 98.6 & 0.3 & 1.0 & 0.0 & 0.1 \\
Norfolk, VA & 9.24 & 93.7 & 2.1 & 0.4 & 3.6 & 0.1 \\
San Diego, CA & 11.52 & 99.6 & 0.0 & 0.0 & 0.3 & 0.0 \\
\hline Source: USAspending gov & & & & &
\end{tabular}

Source: USAspending.gov

Table 1 makes clear that the Navy is the dominant federal government customer in each homeport market, but there is no way to accurately measure how much commercial work occurs in the participating shipyards. These shipyards are private entities that conduct business with 
Running Head: ESTIMATING WARSHIP DEPOT MAINTENANCE DURATIONS

commercial customers, but the relatively lower cost of ship repairs on the global market make it difficult for the U.S. industry to attract international customers (Buzby, 2019). These keypoints suggest that the federal government is responsible for a large portion of the depot maintenance market share at each homeport (called port loading hereafter). If federal port loading is a restrictive factor in maintenance capacity, it can serve as a useful variable to predict future outcomes.

\subsection{Maintenance delay impacts.}

When U.S. shipyards operate at a level and continuous manner, shipyard workers are less likely to experience the peaks and valleys in employment opportunities which have been known to cause retention issues in a private manufacturing industry (Kalafsky, 2008). The Navy and the participating shipyards are engaged in a public-private partnership to maintain the nation's surface fleet of warships and the peaks and valleys are antithetical to growing the workforce needed to maintain an inventory of warships expected to increase over the next few decades (Naval Sea Systems Command, 2019).

Figure 1 compares private industry employment at state levels ${ }^{2}$ with depot maintenance obligations in the continental United States where surface ships are homeported. The industry appears to have responded to demand signals by adjusting employee levels based on federal obligations. Figure 1 shows a strong correlation between the two variables $\left(r^{2}=0.76\right)$, suggesting a relationship can exist at times of peak demand where the labor force is a limiting factor of capacity. Industry human capital is an area that is ripe for future research.

\footnotetext{
2 The U.S. Bureau of Labor Statistics (2020a) deems certain labor force data at municipal levels "Non-Disclosable" preventing its release to the public. The most granular data available was at the state level.
} 
Figure 1. Depot-Level Maintenance Obligations vs. Industry Employees (CA, FL, VA, WA)

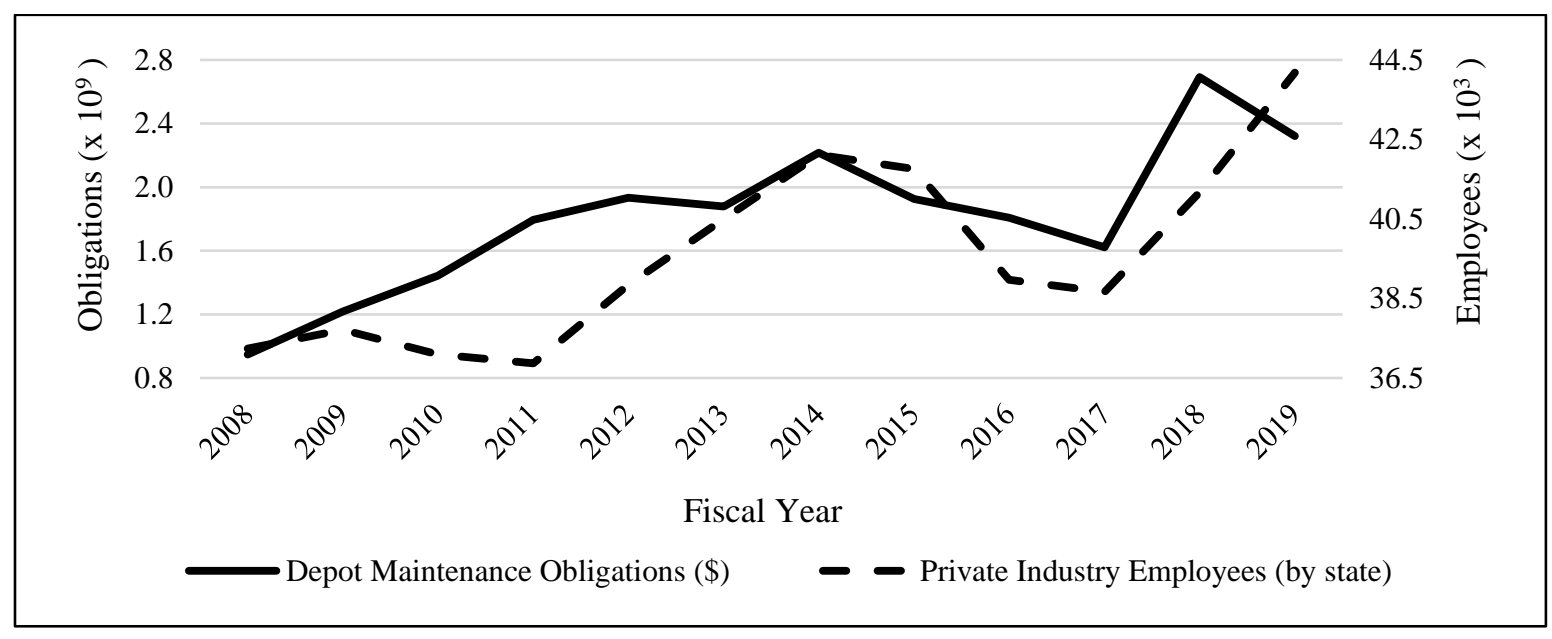

Sources: U.S. Bureau of Labor Statistics \& USAspending.gov

\subsubsection{Resource constraints.}

Another limitation to industry capacity is fixed assets. Shipyards have a finite number of facilities and when the market is loaded there might be insufficient physical space at each shipyard to host several maintenance projects simultaneously. The concern for drydock capacity is discussed in a study conducted for the Navy, (Martin et al., 2017), but overall throughput for waterborne and drydocking maintenance has not been characterized to date. This research does not characterize capacity utilization which is needed to fully optimize the markets, and it is important to note that the data used here was collected from maintenance periods that occurred within the fixed asset constraints described above. Any future growth in the fixed assets or human capital within each market should be considered in future studies.

When schedule overruns occur in a shipyard, other scheduled maintenance is impacted due to space limitations at the berths or in the drydocks. Likewise, an early finish of a shipyard maintenance period could leave industry resources idle until a contract is awarded that provides 
Running Head: ESTIMATING WARSHIP DEPOT MAINTENANCE DURATIONS

stable direct-labor funding to keep the workforce employed. Loading the participating shipyards in a level manner should be the focus of the Navy and the industry.

Warships are complex, high-capital assets that require a large amount of planned maintenance in order to safely and effectively provide national defense capabilities. Unless a ship has an exemption from 10 U.S.C. $\S 8680$ for maintenance in foreign shipyards, all of the planned depot-level maintenance must be accomplished in a U.S. shipyard. The reasons for the strict legislation are beyond the scope of this research, but the legislative mandate has the potential to place maritime national defense capabilities somewhat at the mercy of industry capacity. Ideally, the Navy should understand the markets' production capacities in order to optimize ship repair work and level load the country's participating shipyards in a manner that grows private sector fixed assets and develops the workforce.

\subsection{Impacts to national defense.}

When a warship is delayed from an expected deployment, combatant commanders remain in need of an asset to execute national defense strategies. This means that either the portion of national defense that delayed warships are expected to fill is left unfilled, or another asset is deployed on short notice possibly impacting other aspects of the country's national defense strategy. An understanding of U.S. ship repair yards' production rates and the causes of variance will enable maintenance schedulers to accurately forecast repair durations thus reducing maintenance period extensions and cascading effects on other national defense resources.

\subsection{Theoretical underpinning.}

In economics, production functions are used to study the relationships between the maximum output of a production process and the individual inputs. This research uses the same rationale to conceptualize a method for estimating warship depot maintenance durations. 
Running Head: ESTIMATING WARSHIP DEPOT MAINTENANCE DURATIONS

According to Barzel (1964), the production function can be written in its simplest form as $y=$ $f\left(x_{1}, \ldots, x_{n}\right)$, where $y$ is the output and $x_{i}$ represent the input factors of production. To further define the inputs for production in a shipyard one can look to the KLEMS literature. O'Mahoney and Timmer (2009) explain that KLEMS represents Capital $(K)$, Labor $(L)$, Energy $(E)$, Material $(M)$ and Services $(S)$ which has been modified in Equation 1 to explain the concept in a shipyard context. The maximum output in Equation 1 is represented by $(Q)$ while the subscripts $i$ and $t$ represent each of the five homeport markets and the time period, respectively.

$$
Q_{i t}=f\left(K_{i t}, L_{i t}, E_{i t}, M_{i t}, S_{i t}\right)
$$

Warship depot repair periods require a specified amount of each of the KLEMS inputs and when shipyards submit bid proposals for repair contracts the inputs are embedded in the bid offering. For instance, shipyard work requires a lot of capital to participate because of the amount and costs of the resources used in the business. Bidders must review each maintenance action to be performed during the maintenance period and determine what resources are required to effect specified repairs in a manner that generates a profit for the shipyard. Undeniably, shipyard work is labor intensive (Stopford, 2009), requires a fair amount of electricity and fuel to operate shipyard equipment, large amounts of raw materials are procured and used such as steel plate and copper-nickel piping, and while the vessel sits at a berth or in a drydock for repairs there are a number of services required to maintain and repair ships' systems such as material handling, hotel services and fire water.

The assumption made here is simple: when a bidder submits a formal offer for a prescribed amount of depot maintenance (not including growth work), the KLEMS inputs are part 
Running Head: ESTIMATING WARSHIP DEPOT MAINTENANCE DURATIONS

of the calculus to complete the work in the contracted period of performance. Likewise, once a contract is completed, a history is recorded indicating how much output the Navy received for the combined total of the KLEMS inputs procured and consumed by the vendor to complete the project (i.e., captured in the total cost). Therefore, a relationship can exist between the costs of the depot-level maintenance and the periods of performance that can be harnessed for this research purpose.

\subsection{Summary of background discussion.}

This section argues that the Navy is the dominant customer in participating shipyards where surface ships are homeported and the relationships between maintenance period costs and durations could be useful in estimating future periods of performance. Additionally, the U.S. federal government's high demand for maintenance contributes the overall market load and is hypothesized to have an inverse and significant relationship with the depot maintenance rate of accomplishment. The basic premise of the method explained in Section 3 is that there is a lack of an understanding of the rate of work accomplishment that realistically reflects market capabilities under varying levels of market loading.

\section{Method}

\subsection{Data.}

Data collected for this research includes U.S. federal obligations to private shipyards for maintenance on vessels or equipment occurring between Fiscal Years (FY) 2012 and 2020, where U.S. Navy surface vessels are homeported. Realizing that commercial sector financial data is unavailable and the evidence that state-level labor forces are strongly correlated with federal spending (see Figure 1), it is essential to capture all federal obligations to the shipyards where surface ship depot maintenance occurs in order to fully exploit the impacts of port loading. 
Running Head: ESTIMATING WARSHIP DEPOT MAINTENANCE DURATIONS

This data includes maintenance obligations in U.S. nominal dollars, and periods of performance from all federal government agencies that contracted with participating private shipyards. Aside from planned surface ship depot-level maintenance, U.S. federal agencies who contracted with the participating shipyards include the Army, Coast Guard, MARAD and the Navy to perform work other than surface ship planned depot maintenance. The central focus is to capture every federal obligation to the ship repair markets that would engage participating shipyards in work while surface ship depot maintenance contracts are executed. Only completed contracts for surface ship depot maintenance are used to develop the predictive model and all federal obligations were used in the variable representing market load (called port loading hereafter).

The impacts of inflation were removed from all federal obligations using Producer Price Indices (PPI) which were downloaded from the U.S. Bureau of Labor Statistics (2 Dec 2020). Obligations to MARAD were deflated using the ship repair (non-military) PPI and all others using the PPI for military ship repair. Other indices have been used to deflate nominal dollars in the literature such as the Cost Price Index (Shan, 2014). The point is to demonstrate a need to deflate the data to remove any impacts of inflation and the index used is sufficient for this purpose.

\subsection{Variables.}

An ordinary least squares regression model is used to estimate production rates in U.S. shipyards engaged in surface ship depot maintenance. The dependent variable is Production Rate $(R)$ which is measured as an average of daily economic capacity (Real USD / calendar days). The primary independent variable is the maintenance Obligation $(O)$ which is measured in real U.S. dollars. Controlling for the impacts of simultaneously occurring maintenance in participating 
shipyards is accomplished with the Port Loading $(L)$ variable. This variable is developed by multiplying the production rate of all maintenance periods occurring simultaneously by the number of production days overlapping the maintenance period of interest, also measured in real U.S. Dollars. Equation 2 describes the port loading variable for each planned depot maintenance period $j$ developed from simultaneously occurring maintenance periods $i$ in the homeport market.

$$
\text { Port Loading }_{j}=\sum_{i=1}^{n} \text { Concurrent Production Rate } \text { R }_{i} \times \text { Days Overlap }_{i}
$$

Table 2 summarizes the variables and illustrates the descriptive statistics for each homeport. A noticeable difference is observed in all three variables when comparing the larger markets located in Norfolk, VA and San Diego, CA with the two smaller ports.

Table 2. Descriptive Statistics by Homeport

\begin{tabular}{|c|c|c|c|c|}
\hline Homeport & Statistic & $\begin{array}{r}\mathrm{R} \\
\text { (Real USD } \\
\times 10^{3} / \text { Day) }\end{array}$ & $\begin{array}{r}\mathrm{O} \\
(\text { Real USD } \\
\left.\times 10^{6}\right)\end{array}$ & $\begin{array}{r}\mathrm{L} \\
(\text { Real USD } \\
\left.\times 10^{6}\right)\end{array}$ \\
\hline \multirow{4}{*}{$\begin{array}{l}\text { Norfolk } \\
(\mathrm{n}=105)\end{array}$} & Min & 12.1 & 1.5 & 69.0 \\
\hline & Max & 294.4 & 111.2 & 698.0 \\
\hline & Mean & 62.1 & 21.4 & 246.3 \\
\hline & S.D. & 44.9 & 21.3 & 131.1 \\
\hline \multirow{4}{*}{$\begin{array}{l}\text { San Diego } \\
(\mathrm{n}=92)\end{array}$} & Min & 13.5 & 2.9 & 146.7 \\
\hline & Max & 174.3 & 116.7 & $2,017.4$ \\
\hline & Mean & 61.7 & 23.9 & 688.3 \\
\hline & S.D. & 34.4 & 20.7 & 372.7 \\
\hline \multirow{4}{*}{$\begin{array}{l}\text { Mayport } \\
(\mathrm{n}=21)\end{array}$} & Min & 23.0 & 2.3 & 4.2 \\
\hline & Max & 98.1 & 47.4 & 59.9 \\
\hline & Mean & 56.3 & 16.7 & 24.4 \\
\hline & S.D. & 20.0 & 12.8 & 16.7 \\
\hline \multirow{4}{*}{$\begin{array}{l}\text { Pearl Harbor } \\
(\mathrm{n}=20)\end{array}$} & Min & 24.1 & 3.0 & 25.7 \\
\hline & $\operatorname{Max}$ & 135.4 & 50.2 & 132.6 \\
\hline & Mean & 63.9 & 16.4 & 57.6 \\
\hline & S.D. & 32.7 & 11.1 & 24.9 \\
\hline
\end{tabular}


Running Head: ESTIMATING WARSHIP DEPOT MAINTENANCE DURATIONS

\subsection{Correlations.}

Strong correlations between independent variables indicate the presence of multicollinearity which have the propensity to lead to unreliable regression results. Table 3 illustrates the correlation coefficients by homeport model.

Table 3. Correlation Coefficients

\begin{tabular}{|c|c|c|c|c|}
\hline & & $\mathrm{R}$ & $\mathrm{O}$ & $\mathrm{L}$ \\
\hline \multirow{3}{*}{$\begin{array}{l}\text { Norfolk } \\
(\mathrm{n}=105)\end{array}$} & $\mathrm{R}$ & 1 & & \\
\hline & $\mathrm{O}$ & 0.825 & 1 & \\
\hline & $\mathrm{L}$ & 0.151 & 0.646 & 1 \\
\hline \multirow{3}{*}{$\begin{array}{l}\text { San } \\
\text { Diego } \\
(n=67)\end{array}$} & $\mathrm{R}$ & 1 & & \\
\hline & $\mathrm{O}$ & 0.796 & 1 & \\
\hline & $\mathrm{L}$ & 0.214 & 0.748 & 1 \\
\hline \multirow{3}{*}{$\begin{array}{l}\text { Mayport } \\
(\mathrm{n}=21)\end{array}$} & $\mathrm{R}$ & 1 & & \\
\hline & $\mathrm{O}$ & 0.882 & 1 & \\
\hline & $\mathrm{L}$ & 0.455 & 0.758 & 1 \\
\hline \multirow{3}{*}{$\begin{array}{l}\text { Pearl } \\
\text { Harbor } \\
(\mathrm{n}=20)\end{array}$} & $\mathrm{R}$ & 1 & & \\
\hline & $\mathrm{O}$ & 0.830 & 1 & \\
\hline & $\mathrm{L}$ & 0.103 & 0.570 & 1 \\
\hline
\end{tabular}

All variables in $\log 10$ form.

Because of the strong associations between independent $\mathrm{O}$ and $L$ variables in Table 3, caution is needed to avoid multicollinearity and model bias. If the models are estimated with unacceptable levels of multicollinearity the estimates will be unreliable. Therefore, the Variance Inflation Factor (VIF) is measured after each regression to assess the levels of multicollinearity. According to Hair et al. (2010) higher levels of multicollinearity are reflected in higher VIF values with a value of $<3.0$ being the acceptable threshold. 
Running Head: ESTIMATING WARSHIP DEPOT MAINTENANCE DURATIONS

\subsection{Model specification.}

This section describes the Ordinary Least Squares (OLS) models employed to estimate depot-level maintenance production rates. Each homeport model is specified in Equation 3 where $\varepsilon$ represents the error term.

Production Rate $(R)=$ Obligation $(O)+$ Port Load $(L)+\varepsilon$

Eq. 3

\subsection{Limitations.}

This research is affected by a few limitations. First, without the ability to collect the costs and durations of commercial work, the amount of port loading could not be a accurately represented in the models. The assumption is that the commercial obligations are minimal in these specific markets when compared to federal government obligations, and the former will be captured in the error term.

Second, the contract periods of performance used to develop maintenance period durations do not match actual dates that ships are under repair in a shipyard. The Navy calls these maintenance periods "CNO-Scheduled Availabilities” (Chief of Naval Operations, 2019, p.35) and the dates are not expected to match the availability dates because work is expected to occur both before and after a vessel enters and leaves a shipyard. The purpose of this research is to develop a method for practitioners and the analyst should arrange the data in the most appropriate manner to match the context.

\section{Results}

Before carrying out the regressions all data is transformed to the $\log 10$ form in order to meet the normality assumption of regression. The results of each model are included in Table 4. 
Running Head: ESTIMATING WARSHIP DEPOT MAINTENANCE DURATIONS

Post regression testing for normality included the Shapiro-Wilk test and visual analysis of the residuals, both indicating normal distributions in each model. Additionally, the VIF scores in Table 3 indicate acceptable multicollinearity levels (i.e., < 5.0) as described by Hair et al. (2010).

Table 4. Regression Results and VIF Values

\begin{tabular}{|c|c|c|c|c|}
\hline & $\begin{array}{c}(1) \\
\text { Norfolk }\end{array}$ & $\begin{array}{c}(2) \\
\text { San Diego } \\
\end{array}$ & $\begin{array}{c}\text { (3) } \\
\text { Mayport }\end{array}$ & $\begin{array}{c}(4) \\
\text { Pearl Harbor } \\
\end{array}$ \\
\hline $\log 10(O)$ & $\begin{array}{l}0.862 * * * \\
(0.024)\end{array}$ & $\begin{array}{c}0.930 * * * \\
(0.020)\end{array}$ & $\begin{array}{l}0.583 * * * \\
(0.056)\end{array}$ & $\begin{array}{c}0.818 * * * \\
(0.070)\end{array}$ \\
\hline $\log 10(L)$ & $\begin{array}{l}-0.789 * * * \\
(0.041)\end{array}$ & $\begin{array}{l}-0.825 * * * \\
(0.029)\end{array}$ & $\begin{array}{l}-0.257 * * \\
(0.063)\end{array}$ & $\begin{array}{l}-0.745^{* * * *} \\
(0.133)\end{array}$ \\
\hline Constant & $\begin{array}{l}-2.326 * * * \\
(0.173)\end{array}$ & $\begin{array}{l}2.546^{* * * *} \\
(0.119)\end{array}$ & $\begin{array}{l}-0.438 * \\
(0.177)\end{array}$ & $\begin{array}{l}1.908 * * \\
(0.521)\end{array}$ \\
\hline Pseudo $R^{2}$ & 0.929 & 0.963 & 0.873 & 0.878 \\
\hline$R M S E$ & 0.071 & 0.045 & 0.062 & 0.081 \\
\hline$F$ & 687.8 & 1180.2 & 69.8 & 69.3 \\
\hline$n$ & 106 & 92 & 21 & 20 \\
\hline VIF & 1.72 & 2.27 & 2.35 & 1.48 \\
\hline \multicolumn{5}{|c|}{$\begin{array}{l}\text { Standard errors in parenthesis. All data in Log10 form. Dependent variable is } \\
\text { production rate }(R) \text {. } \\
* \quad p<0.05 \\
* * p<0.01 \\
* * * p<.001\end{array}$} \\
\hline
\end{tabular}

\subsection{Regression interpretations.}

Each of the regression models in Table 4 indicate significant relationships in the predictor variables $(p<0.05)$. Furthermore, each of the Obligation variables' coefficients indicate that the larger the amount obligated, the faster the production rate. This relationship suggests that the larger the contract, the larger the pool of resources brought by the shipyard. Although this makes intuitive sense, there is expected to be a point of diminishing returns. Therefore, the relationship needs to be further characterized to determine the impact of resources constraints such as human capital. 
Running Head: ESTIMATING WARSHIP DEPOT MAINTENANCE DURATIONS

The coefficients for port loading are in the hypothesized direction indicating that the higher the market loading, the slower the production rate. Each of the models with the exception of Model 3, show a Port Loading coefficient that is approximately 90-percent the magnitude of the Obligation variable. This indicates that port loading is not as important to the production rate in Mayport, FL as it is in the other homeports. The reasons are not immediately clear, but will likely to be discovered when the Mayport market is further characterized. Future research is warranted to characterize the economic capacity of each port and each shipyard.

Each of the model's R-squared values are above 0.87 indicating a healthy amount of variance is captured in the models, and the VIF scores are below acceptable levels $(<3.0)$, according to (Hair et al., 2010). These results indicate that the models exhibit acceptable levels of multicollinearity and will provide estimates free from the impacts of endogeneity. Since the models are in the Log10 form one can interpret the percent changes in the dependent and independent variables with ease. For instance, with every one-percent increase in the Obligation, there will be a 0.86 -percent increase in the production rate. And, for every one-percent increase in Port Loading, there is a 0.79 -percent decrease in the production rate. Each of these models have acceptable post regression diagnostics, but the predictive accuracy for estimates outside of the data remains unclear. The next section assesses the generalizability of the models' results to a wider population.

\subsection{Generalizability.}

This section assesses the out-of-sample accuracy of the regression models. Even though the models are free from endogeneity, the predictive accuracy for maintenance periods not used to develop the model remains in question. This is known as out-of-sample accuracy and each of the models in Table 4 were constructed from small samples using all data available. Small 
Running Head: ESTIMATING WARSHIP DEPOT MAINTENANCE DURATIONS

sample sizes make it difficult to partition databases into learning and testing datasets so the Leave-One-Out (LOO) method of cross validation is employed. Although computationally costly, the method removes one record (datapoint) at a time and regresses the remaining data to estimate the excluded record (Hair et al., 2009). Once regressions are completed for each record, the Mean Absolute Errors (MAE), Root Mean Squared Errors (RMSE) and R-squared values are averaged to provide analysts with indicators of accuracy comparable to the original regression models. Table 5 illustrates the results of the LOO analyses.

Table 5. Leave-One-Out Analyses of Regression Models

\begin{tabular}{lcccc}
\hline & $(1)$ & $(2)$ & $(3)$ & $(4)$ \\
& Norfolk & San Diego & Mayport & Pearl Harbor \\
\hline Root Mean Squared Errors & 0.072 & 0.051 & 0.065 & 0.103 \\
Mean Absolute Errors & 0.060 & 0.042 & 0.054 & 0.075 \\
Pseudo $\mathrm{R}^{2}$ & 0.926 & 0.954 & 0.851 & 0.807 \\
\hline
\end{tabular}

Table 5 reveals that the average errors and Pseudo R-squared values remained at acceptable levels during the analysis. Models 1 and 2 are unquestionably more accurate than Models 3 and 4, and all of the models are acceptable for use in predicting future outcomes. These results demonstrate that on average each model's out-of-sample errors and R-squared values remained at reliable levels during the LOO analysis indicating the results of the model are generalizable to the larger population of depot-levels maintenance periods.

\subsection{Estimation method.}

This section provides practitioners with the tools necessary to estimate production rates. The models estimated in Table 4 provide information required to estimate depot-level 
maintenance production rates for each homeport. The formula to convert the estimated production rate $(\hat{R})$ to estimated calendar days $(\widehat{D})$ is represented by Equation 4 .

$$
\text { Duration Days }(\widehat{D})=\frac{\text { Obligations }(O)}{\text { Production Rate }(\widehat{R})}
$$

\subsubsection{Maximum production rates.}

Because each ship class varies in physical size there should be an understanding of the maximum production rates achievable for each class. For instance, the analyst must be sure not to apply an LHD-size production rate to a DDG-size vessel. There are clear spatial differences between the classes that could benefit or restrict work crews across the various ship classes which are noticeable in the data. The maximum values are sufficient demonstration purposes, but an understanding of economically achievable production rates for each class is needed to set maximum limits.

\subsubsection{Estimation example.}

By establishing a maximum economically achievable production rate, an analyst can set constraints for each estimate. For this example, the maximum production rate is taken from the dataset for DDGs involved in drydock maintenance which is 138,000 real USD per calendar day. Table 6 illustrates an example of an \$80-million-dollar drydock maintenance period for a DDGclass vessel occurring at each homeport. The anticipated port loading values in Table 6 represent the average for each planned depot-level maintenance period within each homeport between FY 2017 and 2019. 
Running Head: ESTIMATING WARSHIP DEPOT MAINTENANCE DURATIONS

Table 6. Example Maintenance Period Duration Estimates

\begin{tabular}{lrrrr}
\hline & Norfolk & San Diego & Mayport & Pearl Harbor \\
\hline Maximum Port Loading (Real USD x 10 $0^{6}$ ) & 698.00 & $2,017.00$ & 59.00 & 132.60 \\
Average Port Loading (Real USD x 10 $0^{6}$ ) & 267.33 & 851.34 & 41.93 & 73.99 \\
Nominal Cost of (Real USD x 10 ${ }^{6}$ ) & 80.00 & 80.00 & 80.00 & 80.00 \\
Producer Price Index (Base year 1985) & 1.93 & 1.93 & 1.93 & 1.93 \\
Obligation (Real USD x 10 ${ }^{6}$ ) & 41.45 & 41.45 & 41.45 & 41.45 \\
Production Rate (Real USD x 10 $10^{6}$ Duration Day) & 105.77 & 88.71 & 87.50 & 114.18 \\
Duration Days & 391.89 & 467.27 & 473.70 & 363.02 \\
\hline
\end{tabular}

\subsection{Summary of Results}

This section describes the results by addressing the research questions posed at the end of Section 1. First, the private shipyards that make up each homeport's depot-level maintenance market were taken from USAspending.gov (2020) and posted in the Appendix. These shipyards were awarded federal funds for the purpose of planned depot-level maintenance which was easily identifiable in the dataset. Once these private entities were defined, the markets became manifest thus providing the answer to the first research question.

The second research question investigates whether the total of U.S. federal agencies' contract obligations with the individual markets impact surface ships' depot maintenance durations. Using the results in Table 4 this can be answered in the affirmative. The Production Rate variables are significantly and inversely related to Port Loading. Each model indicates that an increase in the work load in a market will be met with a decrease in the production rate thus increasing the duration of the maintenance period.

The last question explores whether the relationships discovered in this research can be used to reliably predict future maintenance periods. This question is also answered in the affirmative. The regression results and the LOO analyses indicate that the models are free from bias and the predictions made from each model are generalizable to data collected from the population that was not included in the model. 
Running Head: ESTIMATING WARSHIP DEPOT MAINTENANCE DURATIONS

These results demonstrate that it is possible to model surface ship depot maintenance periods of performance using the time-cost relationship and anticipated port loading amounts. The results support the notion that port loading is a limiting factor in production rates and should be captured in order to fully realize the impacts of simultaneously occurring maintenance in the markets.

\section{Conclusion}

This research was a necessary step to develop optimization models for each homeport market. The argument for future research in shipyard optimization is simple. If the production rates are known with a reasonable level of confidence, the optimization models become simple arithmetic. One could argue that the anticipated port loading value is difficult to predict. However, this research found that the ship repair markets at the homeports are predominantly loaded with Navy obligations suggesting an economic rigidity that will allow the Navy to develop an optimization model at the homeport or participating shipyard-level. An optimization model is the logical next step for this niche field.

Future research should model the environment using the relevant data, whether for contracting officers developing periods of performance or the maintenance community determining availability dates compatible with national defense strategies. The point is that the method is reliable and highly useful in more than one context. Future research should also explore the impacts of logistics delays, the Covid-19 Pandemic, the impacts of growth and new work and human capital in general for the shipbuilding and repair workforce. These phenomena are suspected to cause variance in the rates of production and are therefore worthy of further study. 
Running Head: ESTIMATING WARSHIP DEPOT MAINTENANCE DURATIONS

The Navy is involved in a public-private partnership to maintain assets used to protect the American people and their way of life. The private sector is under no obligation to grow itself in order to meet the Navy's demands. This puts the Nation at a severe disadvantage in terms of warship readiness. The United States, and its Navy experienced a similar scenario in the years leading up to World War II and the remedy was to work with the private sector to grow the nations' shipbuilding capacity (Lane, 2001), not to leave it up to the industry to figure out. 
Running Head: ESTIMATING WARSHIP DEPOT MAINTENANCE DURATIONS

\section{References}

Barzel, Yoram. (1964). The production function and technical change in the steam-power industry." Journal of Political Economy, 72, 2, pp. 133-150. doi:10.1086/258883

Bromilow, F. J. (1974). Measurement and scheduling of construction time and cost performance in the building industry." The Chartered Builder, 10, 9, pp. 79-82.

Chief of Naval Operations. (2019). Maintenance policy for Navy ships. Retrieved from: https://www.secnav.navy.mil/doni/Directives/Forms/AllItems.aspx

Commander Naval Surface Forces Pacific and Commander Naval Surface Forces Atlantic. (2018). Surface force training and readiness manual. Retrieved from: http://www.sailorbob.com/files/SURFTRAREDMAN_3502_7.pdf

Czarnigowska, A. and A. Sobotka. (2013). Time - cost relationship for predicting construction duration. Archives of Civil and Mechanical Engineering, 13, 4, pp. 518-526. Retrieved from: https://doi.org/10.1016/j.acme.2013.05.004

Eckstein, M. (2020) "Navy striving for 71\% on-time ship maintenance this year, no extensions by end of 2021." USNI News. Retrieved from: https://news.usni.org/2020/01/23/navystriving-for-71-on-time-ship-maintenance-this-year-no-extensions-by-end-of-2021

Hair, J. F., Black, W. C., Babin, B. J., \& Anderson, R. E. (2010). Multivariate data analysis (Seventh ed.). Upper Saddle River, NJ: Prentice Hall.

Kalafsky, Ronald (2008). Workforce shortages in the manufacturing sector: Evidence from Charlotte. Southeastern Geographer, 48, 2, pp. 236-252. Retrieved from: https://muse.jhu.edu/article/249535/pdf

Martin, B., McMahon, M. E., Riposo, J., Kallimani, J. G., Bohman, A., Ramos, A., Schendt, A. (2017). A Strategic assessment of the future of U.S. Navy ship maintenance: Challenges and opportunities. (RAND Research Report RR-1951-NAVY). Retrieved from: https://www.rand.org/content/dam/rand/pubs/research_reports/RR1900/RR1951/RAND _RR1951.pdf

Lane, F. C. (2001). Ships for victory: A history of shipbuilding under the U.S. Maritime Commission. Baltimore, MD. The Johns Hopkins University Press.

National Bureau of Economic Research. (2016). NBER-CES manufacturing industry database [dataset]. Date accessed December 2, 2020. Retrieved from: https://www.nber.org/research/data/nber-ces-manufacturing-industry-database 
Running Head: ESTIMATING WARSHIP DEPOT MAINTENANCE DURATIONS

Naval Sea Systems Command. (2020). Report to Congress on the long-range plan for maintenance and modernization of naval vessels for fiscal year 2020. Retrieved from: https://www.secnav.navy.mil/fmc/fmb/Documents/20pres/FY20\%20Long\%20Range\%2 0Maintenance+Modernization\%20Plan.pdf

Shan, J., Yu, M., \& Lee, C.-Y. (2014). An empirical investigation of the seaport's economic impact: Evidence from major ports in China. Transportation Research Part E, 69, 41-53.

Stopford, M. (2009). Maritime economics (3rd ed.). New York: Routledge.

U.S. Bureau of Labor Statistics (2020a). NAICS 336611 labor force levels [dataset]. Accessed December 2, 2020.Retrieved from: https://www.bls.gov/data/

U.S. Bureau of Labor Statistics (2020b). Producer Price Index ship building and repair [dataset]. Accessed December 2, 2020.Retrieved from: https://www.bls.gov/data/

U.S. Department of Transportation. (2019). Statement of Mark H. Buzby, Administrator Maritime Administration - Testimony on U.S. maritime and shipbuilding industries: Strategies to improve regulation, economic opportunities and competitiveness. Committee on Transportation and Infrastructure, March 6, 2019. Retrieved from: https://www.transportation.gov/testimony/us-maritime-and-shipbuilding-industriesstrategies-improve-regulation-economic

U.S. Maritime Administration (2020). Number and size of the U.S. flag merchant fleet and its share of the world fleet [dataset]. Retrieved from https://www.bts.gov/content/numberand-size-us-flag-merchant-fleet-and-its-share-world-fleet

USA Spending. (2020) Federal Awards to select private shipyards [dataset]. Accessed December 2, 2020. Retrieved from: USAspending.gov.

United States Code. (1993) Title 10, Section 8680: Overhaul, repair, etc. of vessels in foreign shipyards: restrictions. Retrieved from: https://uscode.house.gov/

United States Government Accountability Office (2019). Navy maintenance: Persistent and substantial ship and submarine maintenance delays hinder efforts to rebuild readiness [Report No. GAO-20-257T]. Retrieved from: https://www.gao.gov/products/GAO-20$257 \mathrm{~T}$

United States Government Accountability Office (2019). Navy shipyards: Actions needed to address the main factors causing maintenance delays for aircraft carriers and submarines [Report No. GAO-20-588]. Retrieved from: https://www.gao.gov/products/GAO-20-588 
Running Head: ESTIMATING WARSHIP DEPOT MAINTENANCE DURATIONS

\section{APPENDIX}

Table A1. Participating Shipyards 2012 - 2020

\begin{tabular}{|l|l|l|}
\hline Home Port & Participating Shipyards & DUNS \# \\
\hline Pearl Harbor, HI & BAE Systems Hawaii Shipyards Inc. & 122762222 \\
& Vigor Marine LLC & 627065423 \\
& Pacific Shipyards International, LLC & 034683537 \\
\hline Mayport, FL & BAE Systems Jacksonville Ship Repair LLC & 002890994 \\
& Metro Machine Corp. & 942868621 \\
& Earl Industries, LLC & 153920269 \\
& Marine Hydraulics International, LLC & 119077303 \\
& North Florida Shipyards, INC. & 093598548 \\
\hline Norfolk, VA & BAE Systems Norfolk Ship Repair Inc. & 003175072 \\
& Metro Machine Corp. & 057917536 \\
& Earl Industries, LLC & 153920269 \\
& Marine Hydraulics International, LLC & 119077303 \\
& Colonna's Ship Yard, Incorporated & 003174273 \\
\hline San Diego, CA & National Steel And Shipbuilding Company & 009158932 \\
& BAE Systems San Diego Ship Repair Inc. & 080911274 \\
& HII San Diego Shipyard Inc. & 001307495 \\
& Vigor Marine & 627065423 \\
& Pacific Ship Repair \& Fabrication, Inc. & 051981918 \\
\hline
\end{tabular}

